\title{
Metal Recovery and Preconcentration by Aminopolycarboxylic Acid modified Silica Surfaces
}

\author{
Eveliina Repo*1, Jolanta K. Warchot ${ }^{2}$, Mika Sillanpä̈̈ ${ }^{3}$ \\ ${ }^{1}$ Laboratory of Green Chemistry, LUT Chemtech, Lappeenranta University of Technology, \\ Skinnarilankatu 34, Lappeenranta, Finland \\ e-mail: eveliina.repo@lut.fi \\ ${ }^{2}$ Department of Water Purification and Protection, Rzeszów University of Technology, \\ al. Powstańców Warszawy 12, Rzeszów, Poland \\ e-mail: jwarchol@prz.edu.pl \\ ${ }^{3}$ Laboratory of Green Chemistry, LUT Chemtech, Lappeenranta University of Technology, \\ Skinnarilankatu 34, Lappeenranta, Finland \\ email: mika.sillanpaa@lut.fi
}

Cite as: Repo, E., Warchoł, J. K., Sillanpää, M., Metal Recovery and Preconcentration by Aminopolycarboxylic Acid modified Silica Surfaces, J. sustain. dev. energy water environ. syst., 5(1), pp 89-100, 2017, DOI: http://dx.doi.org/10.13044/j.sdewes.d5.0135

\begin{abstract}
This study focuses on the adsorption and preconcentration of various metals by silica gel surfaces modified with aminopolycarboxylic acids namely ethylenediaminetetraacetic acid or diethylenetriamine-pentaacetic acid. The adsorption performance of the studied materials was determined in mixed metal solutions and the adsorption isotherm studies were conducted for cobalt, nickel, cadmium, and lead. The results were modeled using various theoretical isotherm equations, which suggested that two different adsorption sites were involved in metal removal although lead showed clearly different adsorption behavior attributed to its lowest hydration tendency. Efficient regeneration of the adsorbents and preconcentration of metals was conducted with nitric acid. Results indicated that the metals under study could be analyzed rather accurately after preconcentration from both pure, saline and ground water samples.
\end{abstract}

\section{KEYWORDS}

Adsorption, Preconcentration, Water treatment, Metal removal, Salt water, Metal analysis.

\section{INTRODUCTION}

Toxic metals, even at very low concentrations, can cause serious environmental problems when released in the water bodies. Especially, metals are not degradable and easily accumulate in food chains. For example cadmium and lead have been stated to be the most hazardous elements to human health [1]. Moreover, rapidly moving industrialization increases the discharge of toxic metals into the environment [2]. Therefore, efficient removal of metals from the wastewater effluents as well as their accurate analysis from various matrices is highly important.

\footnotetext{
${ }^{*}$ Corresponding author
} 
There are various metal removal techniques including sorption (adsorption, ion-exchange), chemical precipitation, membrane filtration, coagulation and flocculation, flotation and electrochemical treatment [3]. Amongst the above methods adsorption offers high efficiency even at low concentrations, cost-effectiveness (depending on the type of adsorbent) and easy operation [4]. Therefore, many different kind of adsorbents have been applied for the metal removal. Among those activated carbon has been the most popular and used for example in the case transition metals [5]. Benefits of activated carbon are high surface area and variety of raw materials that can be used in its production. Since the beginning of this century, nanomaterials have been under intensive study for water purification due to their unique properties such as very high surface area. Nano-adsorbents for metal removal have been reviewed for example by Sharma et al. [4]. In order to obtain environmentally benign and low-cost adsorbents bio-based materials, such as bacteria, algae and fungi, are getting more and more attention [6]. Even though their usage is facing a lot of challenges, their utilization is suggested to become easier in the future. Finally, there exists a huge amount of synthetic [7] and natural [8] minerals, which have been extensively studied for metal adsorption. Most of these adsorbents for example zeolites and clays are inexpensive and usable also in larger scale applications. Furthermore, chemical modification of different adsorbents has become a common method in order to improve or otherwise tailor the properties of the adsorbents such as biomaterials [9] and nanosorbents [10].

In the case of divalent metal ions, adsorption with surfaces modified by chelating agents such as aminopolycarboxylic acids has been of interest in recent years [11]. From the studied materials silica gel has been found as appealing matrix for functionalization due to its high surface coverage of hydroxyl groups, easy availability, high surface area (around $600 \mathrm{~m}^{2} \mathrm{~g}^{-1}$ ), and high thermal resistance. In our earlier studies silica gel was functionalized with Ethylenediaminetetraacetic Acid (EDTA) and Diethylenetriamine-Pentaacetic (DTPA) and produced adsorbents used for the removal of cobalt and nickel from aqueous solutions $[12,13]$. More recently, EDTA has been used to modify graphene in order to remove nickel from the wastewater [14] and EDTA-modified magnetic chitosan used for the lead adsorption [15]. However, graphene is quite expensive material and chitosan not appropriate for the column experiments due to its swelling.

Besides the effective removal of metals from the water bodies accurate determination of trace amounts of metals in environmental samples is highly important. However, the analytical equipment such as Inductively Coupled Plasma-Mass Spectrometry (ICP-MS) or Optical Emission Spectrometry (ICP-OES) are very sensitive to sample matrix such as high concentration of salts [16]. These kind of matrices worsen the quantitation limits of metals remarkably [17]. Preconcentrating metals by chelating adsorbents is one of the most promising techniques to reach reliable results in metal analysis. Therefore, besides metal removal, EDTA and DTPA modified silica gels, due to their selectivity, high stability, and easy regeneration using acidic solutions, can be expected to be excellent adsorbents to be used for preconcentration of metals [12]. Moreover, some other aminopolycarboxylic acid based adsorbents have been earlier used successfully in preconcentration experiments. For example, trace elements have been determined from seawater by ICP-MS after pre-concentration using a column filled with iminodiacetic acid resin [18] and analysis of trace metals in seawater conducted using nitrilotriacetate resin [19]. Furthermore, in a very recent paper Cyclodrexin modified with EDTA was successfully used for the preconcentration of rare earth elements prior to analysis with ICP-OES [20].

The purpose of this study was to investigate the feasibility of EDTA or DTPA modified silica surfaces (EDSG and DTSG) for adsorption and preconcentration of various heavy metal cations including Cobalt (Co), Nickel (Ni), Cadmium (Cd), Lead $(\mathrm{Pb})$, and Zinc $(\mathrm{Zn})$ from aqueous solutions. The efficiency of studied materials was not 
earlier tested in multimetal solutions from different matrices. Also, there was a lack of knowledge how these materials behave in the preconcentration studies. Therefore, unlike our earlier studies, the focus of this study was to apply these highly potential adsorbents for the removal of wider range of metals from different solution matrices and preconcentration of trace amounts of metals to improve their analysis accuracy.

\section{MATERIALS AND METHODS}

Materials and methods used in this study were selected based on the earlier findings. All the steps were conducted carefully avoiding the formation of harmful components and extra waste. The procedures conducted are described below.

\section{Chemicals}

All the chemicals used in this study were of analytical grade and used as received. Nitrate salts used for preparation of metal stock solutions were acquired from Sigma-Aldrich. Working solutions ranging from 1 to $800 \mathrm{mg} / \mathrm{l}(0.02$ to $4 \mathrm{mmol} / \mathrm{l})$ were made from the stock solutions. Adjustment of $\mathrm{pH}$ was made with $0.1 \mathrm{M}$ Sodium hydroxide $(\mathrm{NaOH})$ and $0.1 \mathrm{M}$ Nitric acid $\left(\mathrm{HNO}_{3}\right)$. Multimetal solutions were prepared by at first adding acid in the flasks in order to avoid any precipitation and conducting adsorption experiments immediately with fresh solutions. Analysis of solutions before adsorption experiments confirmed that metals were in ionic form.

\section{Modification and characterization of silica gels}

EDSG and DTSG were synthesized by reacting EDTA- or DTPA-anhydrides with aminopropyl-modified silica gels in ethanol/acetic acid solution. The synthesis of modified surfaces followed the reported procedures [21] and more detailed information of the whole synthesis process can be found in our earlier publication [12]. The characterization of the products was conducted by elemental analysis, surface area and pore size analysis and zeta potential analysis and the properties of the studied materials are presented in Table 1 .

Table 1. Properties of the modified silica gels

\begin{tabular}{cccccc}
\hline Adsorbents & $\begin{array}{c}\text { Particle size } \\
{[\mu \mathrm{m}]}\end{array}$ & $\begin{array}{c}\text { EDTA/DTPA } \\
{[\mathrm{mmol} / \mathrm{g}]}\end{array}$ & $\begin{array}{c}\text { Specific } \\
\text { surface area } \\
{\left[\mathrm{m}^{2} / \mathrm{g}\right]}\end{array}$ & $\begin{array}{c}\text { Total pore } \\
\text { volume } \\
{\left[\mathrm{cm}^{3} / \mathrm{g}\right]}\end{array}$ & $\begin{array}{c}\text { Point of } \\
\text { zero-charge }\end{array}$ \\
\hline EDSG & $40-63$ & 0.32 & 384 & 0.48 & 4.0 \\
DTSG & $40-63$ & 0.23 & 328 & 0.41 & 4.0 \\
\hline
\end{tabular}

\section{Batch adsorption studies}

The effective parameters such as adsorbent concentration, contact time, and $\mathrm{pH}$ were optimized in our earlier studies. As observed earlier the maximum metal adsorption was reached at $\mathrm{pH}$ 3. This value is close to the isoelectric points of both EDSG and DTSG. The used dose of adsorbent was $2 \mathrm{~g} / \mathrm{l}$ and contact time 24 hours.

Batch adsorption experiments were conducted at ambient temperature. The sample tubes containing metal solution and the adsorbent were agitated on a rotary shaker. After experiment the adsorbent was separated from aqueous solution using $0.45 \mu \mathrm{m}$ polypropylene syringe filter and the residual concentration of metal in the samples were analyzed by an Inductively Coupled Plasma Optical Atomic Emission Spectrometry (ICP-OES) model iCAP 6300 (Thermo Electron Corporation, USA). The adsorption capacities $\left(q_{\mathrm{e}}\right)(\mathrm{mg} / \mathrm{g})$ of modified silica surfaces are calculated as follows: 


$$
q_{\mathrm{e}}=\frac{\left(C_{\mathrm{i}}-C_{\mathrm{e}}\right)}{M} V
$$

where $C_{\mathrm{i}}$ and $C_{\mathrm{e}}$ are the initial and the equilibrium concentrations of the metal ions, respectively (mg/l); while $M(\mathrm{~g})$ and $V(\mathrm{l})$ represent the weight of the adsorbent and the volume of the solution, respectively.

\section{Regeneration studies}

The exhausted adsorbent containing the adsorbed metals was collected for regeneration. Initially the adsorbent was loaded by the metal ions by mixing $0.02 \mathrm{~g}$ of EDSG or DTSG with 0.021 of $10 \mathrm{mg} / \mathrm{l}$ metals solution. After attaining the equilibrium the adsorbent was separated from the solution with centrifuge. Metal ions were eluted by mixing the adsorbent with $5 \mathrm{ml}$ of $2 \mathrm{M} \mathrm{HNO}_{3}$. Effluents were collected and chemically analyzed for metal determination. The regeneration efficiency (\%RE) of the adsorbent was calculated using eq. (2):

$$
(\% R E)=\frac{q_{\mathrm{r}}}{q_{0}} \times 100
$$

where $q_{0}$ and $q_{\mathrm{r}}$ are the adsorption capacity of original and regenerated adsorbent respectively.

\section{Preconcentration studies}

At first solutions spiked with $1 \mu \mathrm{g} / \mathrm{l}$ of metals were prepared by pipetting $0.5 \mathrm{ml}$ of $1 \mathrm{mg} / \mathrm{l}$ stock solutions (diluted from $100 \mathrm{mg} / \mathrm{l}$ standard solutions) in $500 \mathrm{ml}$ flasks followed by dilution with ultrapure water. This solution was pumped with Watson Marlow peristaltic pump Sci-Q 323 through the column [minicolumns purchased from BioRad (EconoColumn, $0.7 \times 10 \mathrm{~cm}$ )] filled with adsorbent with the flow rate of $0.5 \mathrm{ml} / \mathrm{min}$. The volume of the adsorbent was approximately $0.75 \mathrm{ml}$. Additional rinsing was made with $20 \mathrm{~mL}$ of deionized water. The metal elution was conducted with $5 \mathrm{ml}$ of $2 \mathrm{M}$ or $3 \mathrm{M} \mathrm{HNO}_{3}$ and the effluent used for metal analysis. $3 \% \mathrm{NaCl}$ and Allard ground water were also used as matrices in order to confirm the preconcentration efficiency from the various surroundings.

\section{Isotherms}

To theoretically evaluate the adsorption processes of different cations a total number of seven different isotherm models were used (Table 2).

Shortly the Langmuir isotherm assumes that adsorption occurs at specific homogenous sites of the adsorbent without any interactions between the adsorbates and the Freundlich isotherm is applicable for heterogeneous surfaces [23]. The Sips and Redlich-Peterson isotherms are combinations of the Langmuir and Freundlich isotherms $[24,25]$. Toth model is an empirical equation, which was derived to improve Langmuir model fittings at both low and high concentration limits and it is useful in modeling heterogeneous adsorption processes [26]. Dubinin-Reduschovich isotherm is based on the potential theory and assumes a Gaussian energy distribution. Finally, Two-site Langmuir (BiLangmuir) isotherm containing four parameters assumes that the adsorbent surface has two divergent active sites with different affinities toward target compounds [27]. 
Table 2. Adsorption isotherms used in this study

\begin{tabular}{|c|c|c|c|}
\hline & Equation & Parameters & Ref. \\
\hline Langmuir & $q_{\mathrm{e}}=\frac{q_{\mathrm{mL}} K_{\mathrm{L}} C_{\mathrm{e}}}{1+K_{\mathrm{L}} C_{\mathrm{e}}}$ & $\begin{aligned} q_{\mathrm{mL}} & =\underset{\text { maximum ads }}{ } \\
& \text { capacity } \\
K_{\mathrm{L}}= & \text { affinity constant }\end{aligned}$ & {$[22,23]$} \\
\hline Freundlich & $q_{\mathrm{e}}=K_{\mathrm{F}} C_{\mathrm{e}}^{n_{\mathrm{F}}}$ & $\begin{array}{l}K_{\mathrm{F}}, n_{\mathrm{F}}=\text { Freundlich } \\
\text { adsorption constants }\end{array}$ & {$[22,23]$} \\
\hline Sips & $q_{\mathrm{e}}=\frac{q_{\mathrm{mS}}\left(K_{\mathrm{S}} C_{\mathrm{e}}\right)^{n_{\mathrm{S}}}}{1+\left(K_{\mathrm{S}} C_{\mathrm{e}}\right)^{n_{\mathrm{S}}}}$ & $\begin{array}{c}q_{\mathrm{mS}}=\underset{\text { maximum ads }}{\text { capacity }} \\
K_{\mathrm{S}}=\text { affinity constant } \\
n_{\mathrm{S}}=\text { heterogeneity factor }\end{array}$ & {$[22,24]$} \\
\hline $\begin{array}{l}\text { Redlich- } \\
\text {-Peterson }\end{array}$ & $q_{\mathrm{e}}=\frac{q_{\mathrm{mRP}} K_{\mathrm{RP}} C_{\mathrm{e}}}{1+\left(K_{\mathrm{RP}} C_{\mathrm{e}}\right)^{n_{\mathrm{RP}}}}$ & $\begin{array}{l}\text { Either same meanings } \\
\text { than in the Sips equation } \\
\text { or parameters without } \\
\text { physical meaning }\end{array}$ & {$[22,25]$} \\
\hline Toth & $q_{\mathrm{e}}=\frac{q_{\mathrm{mT}} C_{\mathrm{e}}}{\left(b_{\mathrm{T}}+C_{\mathrm{e}}^{n_{\mathrm{T}}}\right)^{\frac{1}{n_{\mathrm{T}}}}}$ & $\begin{array}{c}q_{\mathrm{mT}}=\text { maximum ads. } \\
\text { capacity } \\
a_{\mathrm{T}}=\text { adsorptive potential } \\
\text { constant } \\
n_{\mathrm{T}}=\text { Toth's heterogeneity } \\
\text { factor }\end{array}$ & {$[22,26]$} \\
\hline $\begin{array}{c}\text { Dubinin- } \\
\text {-Radushkevich }\end{array}$ & $q_{\mathrm{e}}=q_{\mathrm{m}} \exp \left(-b_{\mathrm{DR}}\left(\ln \left(1+\frac{1}{C_{\mathrm{e}}}\right)\right)^{2}\right)$ & $\begin{array}{c}E=\frac{1}{\sqrt{2 B_{\mathrm{DR}}}}=\text { adsorption } \\
\text { energy } B_{\mathrm{DR}}=\frac{b_{\mathrm{DR}}}{(R T)^{2}}\end{array}$ & [22] \\
\hline BiLangmuir & $q_{\mathrm{e}}=\frac{q_{\mathrm{mBL} 1} K_{\mathrm{BL} 1} C_{\mathrm{e}}}{1+K_{\mathrm{BL} 1} C_{\mathrm{e}}}+\frac{q_{\mathrm{mBL} 2} K_{\mathrm{BL} 2} C_{\mathrm{e}}}{1+K_{\mathrm{BL} 2} C_{\mathrm{e}}}$ & $\begin{aligned} q_{\mathrm{mBL} 1 / 2} & =\text { maximum ads. } \\
& \text { capacities } \\
K_{\mathrm{BL} 1 / 2}= & \text { affinity constants }\end{aligned}$ & [27] \\
\hline
\end{tabular}

\section{RESULTS AND DISCUSSION}

In this study modified silica gels were used in the adsorption and preconcentration of various metals. The most important findings and discussion related are presented in this chapter.

\section{Multimetal adsorption}

In order to study metal adsorption properties of EDSG and DTSG multimetal solutions with various concentrations were prepared for batch adsorption studies. Table 3 shows that EDSG and DTSG were effective for the removal of divalent metals (as observed earlier) but failed in the removal of metallic oxyanions [Arsenic (As), Chromium (Cr)]. The partial removal of chromium, however, could be due to reduction of chromium to cationic form $\mathrm{Cr}^{3+}$ by EDTA or DTPA. Based on these results it was suggested that adsorption occurred through the surface chelating groups, which are able to form stable complexes with cationic metal ions. Based on the results $\mathrm{Co}, \mathrm{Ni}, \mathrm{Cd}$, and $\mathrm{Pb}$ were selected for the further studies. 
Table 3. Adsorption efficiency of EDSG and DTSG in mixed metal solutions

\begin{tabular}{ccccccccccc}
\hline & $\mathrm{pH}$ & {$[\mathrm{mg} / \mathrm{l}]$} & $\mathrm{As}$ & $\mathrm{Cd}$ & $\mathrm{Co}$ & $\mathrm{Cr}$ & $\mathrm{Cu}$ & $\mathrm{Ni}$ & $\mathrm{Pb}$ & $\mathrm{Zn}$ \\
\hline \multirow{6}{*}{ EDSG } & 3 & 0.1 & 1.9 & 98.9 & 95.6 & 10.3 & 96.4 & 97.0 & 100.0 & 95.0 \\
& 3 & 0.5 & 0.0 & 98.5 & 95.6 & 9.0 & 96.4 & 96.1 & 99.2 & 95.3 \\
& 3 & 1 & 0.0 & 99.0 & 97.0 & 9.4 & 97.7 & 96.4 & 99.1 & 97.5 \\
& 3 & 10 & 0.0 & 68.5 & 68.4 & 30.6 & 8.9 & 98.4 & 73.5 & 97.9 \\
& 4 & 0.1 & 0.0 & 99.1 & 97.0 & 89.7 & 91.1 & 98.8 & 100.0 & 93.4 \\
& 4 & 0.5 & 0.0 & 99.2 & 97.8 & 50.5 & 97.9 & 99.2 & 98.8 & 98.1 \\
& 4 & 1 & 0.0 & 99.1 & 97.8 & 14.9 & 96.9 & 98.4 & 98.6 & 97.6 \\
\hline \multirow{5}{*}{ DTSG } & 3 & 0.1 & 0.0 & 94.3 & 95.2 & 0.0 & 91.2 & 75.6 & 84.9 & 93.6 \\
& 3 & 0.5 & 0.0 & 97.2 & 92.1 & 7.8 & 98.2 & 76.4 & 97.6 & 96.3 \\
& 3 & 1 & 0.0 & 96.9 & 78.8 & 7.4 & 99.8 & 69.6 & 99.1 & 89.1 \\
& 3 & 10 & 0.0 & 60.1 & 60.0 & 2.4 & 9.8 & 97.7 & 16.8 & 90.4 \\
& 4 & 0.1 & 0.0 & 97.7 & 92.9 & 97.2 & 91.0 & 90.9 & 68.7 & 96.0 \\
& 4 & 0.5 & 0.0 & 98.0 & 94.8 & 61.5 & 97.1 & 91.0 & 95.2 & 97.5 \\
& 4 & 1 & 0.0 & 98.2 & 96.5 & 20.8 & 98.1 & 91.6 & 96.9 & 98.4 \\
\hline
\end{tabular}

\section{Adsorption isotherms}

Experimental adsorption isotherms were measured for $\mathrm{Co}, \mathrm{Ni}, \mathrm{Cd}$, and $\mathrm{Pb}$. Isotherm models were fitted by the non-linear regression using MATLAB. Theoretical calculations included the most commonly applied Langmuir and Freundlich isotherms, but also five additional models including the Sips, Redlich-Peterson, Toth, Dubinin-Radushkevich, and BiLangmuir. Notice that Table 4 is showing concentrations of metals in $\mathrm{mmol} / \mathrm{g}$ instead of $\mathrm{mg} / \mathrm{g}$ for the sake of the easier comparison.

Table 4. Adsorption isotherm parameters for metal adsorption by EDSG

\begin{tabular}{|c|c|c|c|c|c|c|}
\hline & $\begin{array}{c}\text { Type of } \\
\text { metal }\end{array}$ & & & & & \\
\hline \multirow{5}{*}{ Langmuir } & & $q_{\mathrm{m}, \exp }[\mathrm{mmol} / \mathrm{g}]$ & $q_{\mathrm{mL}}[\mathrm{mmol} / \mathrm{g}]$ & $K_{\mathrm{L}}[1 / \mathrm{mmol}]$ & & $R^{2}$ \\
\hline & Co & 0.304 & 0.278 & 54.14 & & 0.937 \\
\hline & $\mathrm{Ni}$ & 0.333 & 0.299 & 66.61 & & 0.914 \\
\hline & $\mathrm{Cd}$ & 0.279 & 0.245 & 76.92 & & 0.937 \\
\hline & $\mathrm{Pb}$ & 0.316 & 0.306 & 107.4 & & 0.970 \\
\hline \multirow{5}{*}{ Freundlich } & & $q_{\mathrm{m}, \exp }[\mathrm{mmol} / \mathrm{g}]$ & & $K_{\mathrm{F}}[1 / \mathrm{mmol}]$ & $n_{\mathrm{F}}$ & $R^{2}$ \\
\hline & Co & 0.304 & & 0.273 & 5.131 & 0.953 \\
\hline & $\mathrm{Ni}$ & 0.333 & & 0.307 & 5.575 & 0.934 \\
\hline & $\mathrm{Cd}$ & 0.279 & & 0.273 & 4.711 & 0.938 \\
\hline & $\mathrm{Pb}$ & 0.316 & & 0.315 & 5.985 & 0.794 \\
\hline \multirow{5}{*}{ Sips } & & $q_{\mathrm{m}, \exp }[\mathrm{mmol} / \mathrm{g}]$ & $q_{\mathrm{ms}}[\mathrm{mmol} / \mathrm{g}]$ & $K_{\mathrm{S}}[1 / \mathrm{mmol}]$ & $n_{\mathrm{S}}$ & $R^{2}$ \\
\hline & Co & 0.304 & 0.372 & 11.19 & 0.449 & 0.986 \\
\hline & $\mathrm{Ni}$ & 0.333 & 0.385 & 19.16 & 0.468 & 0.978 \\
\hline & $\mathrm{Cd}$ & 0.279 & 0.315 & 22.28 & 0.519 & 0.984 \\
\hline & $\mathrm{Pb}$ & 0.316 & 0.299 & 118.3 & 1.202 & 0.972 \\
\hline \multirow{5}{*}{ Redlich-Peterson } & & $q_{\mathrm{m}, \exp }[\mathrm{mmol} / \mathrm{g}]$ & $q_{\mathrm{mRP}}[\mathrm{mmol} / \mathrm{g}]$ & $K_{\mathrm{RP}}[1 / \mathrm{mmol}]$ & $n_{\mathrm{RP}}$ & $R^{2}$ \\
\hline & $\mathrm{Co}$ & 0.304 & 0.278 & 115.6 & 0.880 & 0.994 \\
\hline & $\mathrm{Ni}$ & 0.333 & 0.307 & 142.8 & 0.890 & 0.987 \\
\hline & $\mathrm{Cd}$ & 0.279 & 0.265 & 151 & 0.878 & 0.993 \\
\hline & $\mathrm{Pb}$ & 0.316 & 0.309 & 114.6 & 0.981 & 0.972 \\
\hline \multirow{5}{*}{ Toth } & & $q_{\mathrm{m}, \exp }[\mathrm{mmol} / \mathrm{g}]$ & $q_{\mathrm{mT}}[\mathrm{mmol} / \mathrm{g}]$ & $b_{\mathrm{T}}[1 / \mathrm{mmol}]$ & $n_{\mathrm{T}}$ & $R^{2}$ \\
\hline & $\mathrm{Co}$ & 0.304 & 0.411 & 736.5 & 3.231 & 0.989 \\
\hline & $\mathrm{Ni}$ & 0.333 & 0.416 & 754.0 & 2.974 & 0.981 \\
\hline & $\mathrm{Cd}$ & 0.279 & 0.346 & 490.0 & 2.750 & 0.988 \\
\hline & $\mathrm{Pb}$ & 0.316 & 0.303 & 100.0 & 0.925 & 0.970 \\
\hline \multirow{5}{*}{ Dubinin-Radushkevich } & & $q_{\mathrm{m}, \exp }[\mathrm{mmol} / \mathrm{g}]$ & $q_{\mathrm{mRP}}[\mathrm{mmol} / \mathrm{g}]$ & $b_{\mathrm{DR}}$ & $E[\mathrm{~kJ} / \mathrm{mol}]$ & $R^{2}$ \\
\hline & $\mathrm{Co}$ & 0.304 & 0.283 & 0.0489 & 7.67 & 0.961 \\
\hline & $\mathrm{Ni}$ & 0.333 & 0.309 & 0.0448 & 8.02 & 0.956 \\
\hline & $\mathrm{Cd}$ & 0.279 & 0.259 & 0.0448 & 8.02 & 0.974 \\
\hline & $\mathrm{Pb}$ & 0.316 & 0.321 & 0.0373 & 8.79 & 0.938 \\
\hline \multirow{5}{*}{ BiLangmuir } & & $q_{\mathrm{m}, \exp }[\mathrm{mmol} / \mathrm{g}]$ & $q_{\mathrm{mBL} 1}[\mathrm{mmol} / \mathrm{g}]$ & $K_{\mathrm{BL} 1}[1 / \mathrm{mmol}]$ & $q_{\mathrm{mBL} 2}[\mathrm{mmol} / \mathrm{g}] K_{\mathrm{BL} 2}[1 / \mathrm{mmol}]$ & $R^{2}$ \\
\hline & Co & 0.304 & 0.184 & 138.3 & 0.154 & 0.997 \\
\hline & $\mathrm{Ni}$ & 0.333 & 0.206 & 175.3 & 2.051 & 0.992 \\
\hline & $\mathrm{Cd}$ & 0.279 & 0.171 & 189 & 2.146 & 0.996 \\
\hline & $\mathrm{Pb}$ & 0.316 & 0.289 & 119.9 & 0.748 & 0.974 \\
\hline
\end{tabular}


Based on the results in Table 4 and Figure 1 the BiLangmuir isotherm was most applicable to represent the adsorption processes of all the metals with quite high correlation coefficients (results for DTSG not shown here). This indicated that the surface was composed of two different kinds of active sites having different affinities towards target cations. Similar observations were done in the case of $\mathrm{Co}$ and $\mathrm{Ni}$ adsorption on EDSG and DTSG in our earlier studies [12]. Later those two different adsorption sites were attributed to different $\mathrm{pH}$ dependent speciations of the immobilized EDTA and DTPA groups [28].

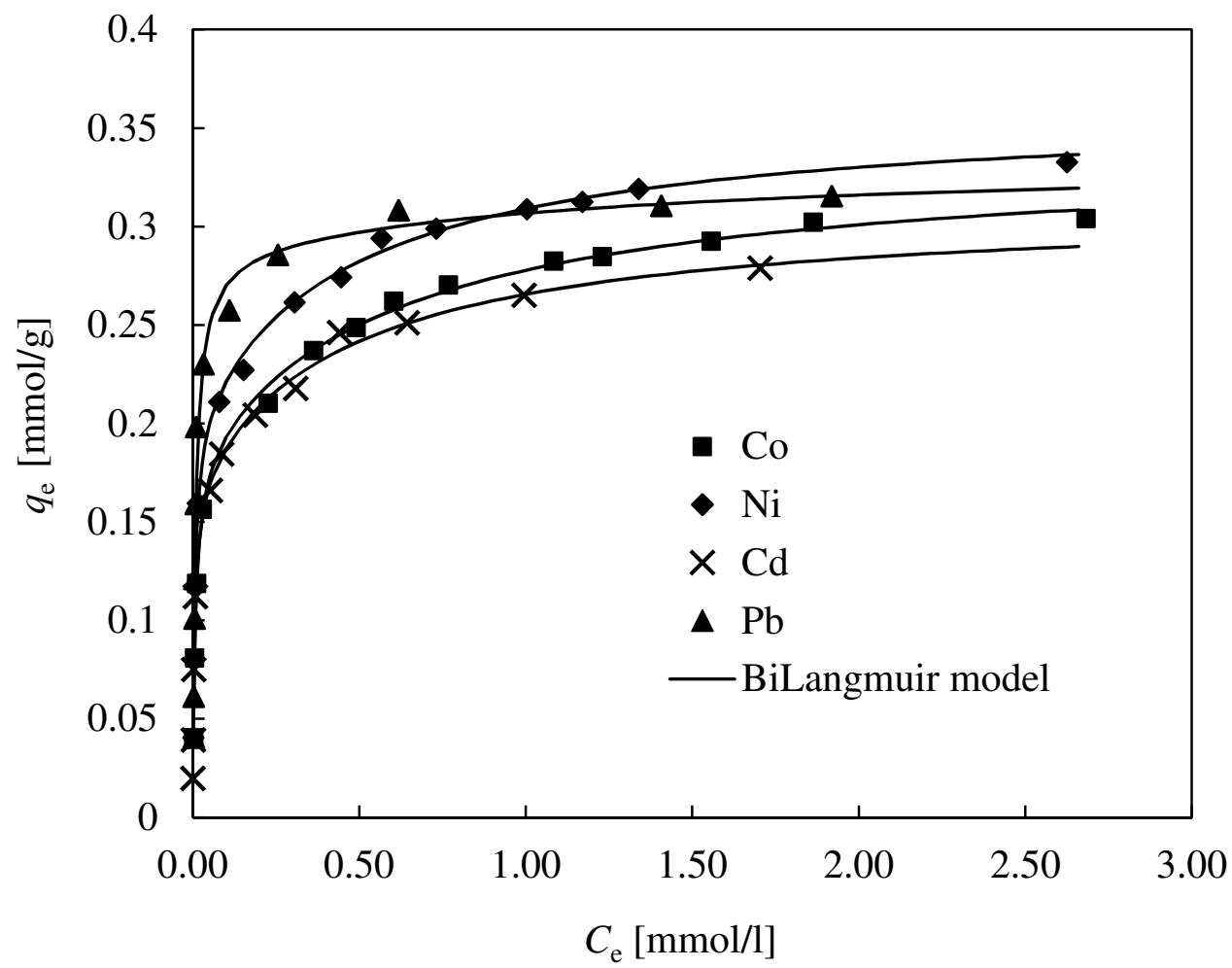

Figure 1. Adsorption isotherms for EDSG

It was noticed that the shapes of the experimental adsorption isotherms for $\mathrm{Pb}$ were clearly different compared to isotherms of other metals. Also, BiLangmuir model suggested that most of the active sites for $\mathrm{Pb}$ binding were similar. Generally, $\mathrm{Pb}$ has the lowest hydration number (it is weakly hydrated) compared to other studied metals, which presumably makes it more easily attached by the surface groups. This is supported by the higher binding energy values of $\mathrm{Pb}$ evaluated by the Dubinin-Raduskevich model (Tables 4 and S1). On the other hand, it should be noted that based on the stability constant values $(\log K)$ of metal chelates under concern (for EDTA - Ni: 20.11, $\mathrm{Pb}: 19.71$, Co: 18.16, and Cd: 18.1, for DTPA - Ni: 22.25, Cd: 21.15, Pb: 20.95 and Co: 20.95) Ni should have the highest binding energies on both EDSG and DTSG. This discrepancy has been observed earlier and is most likely related to immobilization of chelating agents and the weakest hydration tendency of $\mathrm{Pb}$ [29].

Generally the binding energy values and other isotherm parameters related to surface affinity towards target compounds (log $K$-values) were higher for DTSG than for EDSG, which is in accordance with the higher stability constants of metal DTPA-chelates compared to corresponding chelates with EDTA. Especially, Pb seemed to have the highest attraction toward DTSG surface. For further confirmation Figure 2 shows that $\mathrm{Pb}$ was best adsorbed also in multimetal solutions containing the same molar amount of each metal. $\mathrm{Ni}$ was the second best adsorbed followed by $\mathrm{Cd}$ and $\mathrm{Co}$. 


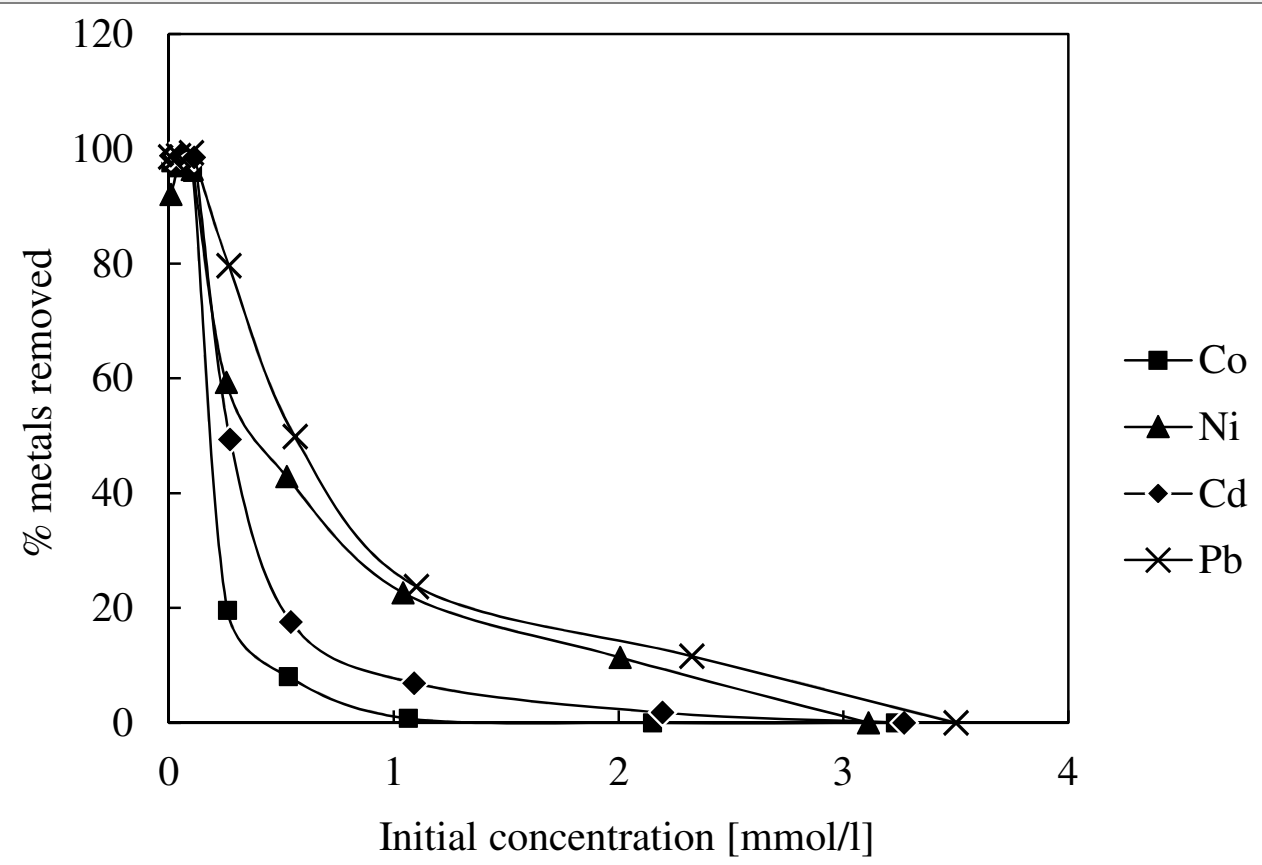

Figure 2. Metal removal by DTSG in the mixed metal solution as a function on initial concentration

\section{Regeneration of the adsorbents}

In order to evaluate the technical applicability of the adsorbents towards real samples containing variety of different metals adsorption/desorption experiments were conducted using multimetal systems. The aim was to clarify if the adsorbent is capable of simultaneous and efficient adsorption and desorption of various metal cations. Regeneration was conducted with $2 \mathrm{M} \mathrm{HNO}_{3}$ and the results are presented in Table 5.

Table 5. The regeneration efficiency of EDSG and DTSG surfaces

\begin{tabular}{ccccccc}
\hline & \multicolumn{3}{c}{ Adsorption capacity of EDSG } & \multicolumn{3}{c}{ Adsorption capacity of DTSG } \\
\hline Metal & $\begin{array}{c}\text { Before } \\
\text { regeneration } \\
{[\mathrm{mg} / \mathrm{g}]}\end{array}$ & $\begin{array}{c}\text { After 4 } \\
\text { regeneration } \\
{[\mathrm{mg} / \mathrm{g}]}\end{array}$ & $\begin{array}{c}\text { Efficiency } \\
{[\%]}\end{array}$ & $\begin{array}{c}\text { Before } \\
\text { regeneration } \\
{[\mathrm{mg} / \mathrm{g}]}\end{array}$ & $\begin{array}{c}\text { After 4 } \\
\text { regenerations } \\
{[\mathrm{mg} / \mathrm{g}]}\end{array}$ & $\begin{array}{c}\text { Efficiency } \\
{[\%]}\end{array}$ \\
\hline $\mathrm{Co}$ & 2.44 & 2.37 & 97.2 & 2.34 & 1.92 & 82.1 \\
$\mathrm{Ni}$ & 4.38 & 4.08 & 93.3 & 4.13 & 3.84 & 92.8 \\
$\mathrm{Cd}$ & 3.80 & 3.71 & 97.7 & 4.61 & 4.38 & 95.1 \\
$\mathrm{~Pb}$ & 4.41 & 4.39 & 99.5 & 4.40 & 4.33 & 98.5 \\
\hline
\end{tabular}

The results show that nitric acid is regenerating the adsorbed metal cations from EDSG with efficiencies up to $99.5 \%$ and from DTSG with efficiencies up to $98.5 \%$ in four consecutive regeneration processes. These results also support the higher binding energies between metals and surface bound DTPA-groups than those between metals and EDTA-groups. In the case of DTSG better regeneration could have been obtained with more concentrated nitric acid.

\section{Preconcentration studies}

Preconcentration of metals is highly important in order to obtain reliable analysis results of trace amounts of metals from the various solution matrices. In this study metals were preconcentrated from pure, simulated ground water, and saline solutions. The sample matrices included single metal solutions, mixed metal solutions, mixed metal solutions with $3 \% \mathrm{NaCl}$ and mixed metal solutions in Allard ground water. All samples 
were spiked with $1 \mu \mathrm{g} / \mathrm{l}$ of metals under study. The results are collected in Table 6 . Firstly, it can be seen that the determination limits even in pure water were remarkably higher than the amounts determined after preconcentration step. In addition, the present of salt increased the limit of determination notable, especially in the case of $\mathrm{Ni}$. Generally, preconcentration was quite successful with recoveries up to $99.4 \%$ for both EDSG and DTSG expect for Cd in mixed metal solutions. In the case of ground water matrix especially $\mathrm{Ni}$ and $\mathrm{Cd}$ were effectively preconcentrated and analyzed.

Table 6. Results of preconcentration studies

\begin{tabular}{|c|c|c|c|c|}
\hline Solution & $\begin{array}{c}\text { Determination } \\
\text { limit in water } \\
{[\mu \mathrm{g} / \mathrm{l}]}\end{array}$ & $\begin{array}{l}\text { Real concentration } \\
{[\mu \mathrm{g} / 1]}\end{array}$ & $\begin{array}{l}\text { Determined after } \\
\text { preconcentration using } \\
\text { EDSG }[\mu \mathrm{g} / 1][\%]\end{array}$ & $\begin{array}{c}\text { Determined after } \\
\text { preconcentration using } \\
\text { DTSG }[\mu \mathrm{g} / 1][\%]\end{array}$ \\
\hline \multicolumn{5}{|c|}{ Single-metal } \\
\hline Co & 5.2 & 1.00 & 0.99 (99.4) & $1.06(94.5)$ \\
\hline $\mathrm{Ni}$ & 2.5 & 1.00 & $1.06(94.5)$ & $1.19(80.6)$ \\
\hline $\mathrm{Cd}$ & 1.9 & 1.00 & $1.15(84.6)$ & $1.01(99.4)$ \\
\hline $\mathrm{Pb}$ & 12.4 & 1.00 & $0.91(91.0)$ & $0.91(90.7)$ \\
\hline \multicolumn{5}{|c|}{ Mixed metal } \\
\hline Co & 5.2 & 1.00 & $0.98(98.1)$ & $1.17(83.4)$ \\
\hline $\mathrm{Ni}$ & 2.5 & 1.00 & $1.04(96.4)$ & $1.08(92.4)$ \\
\hline $\mathrm{Cd}$ & 1.9 & 1.00 & $1.40(60.0)$ & $1.33(66.6)$ \\
\hline $\mathrm{Pb}$ & 12.4 & 1.00 & $0.97(97.0)$ & $1.01(99.1)$ \\
\hline \multicolumn{5}{|c|}{ Mixed metal in $3 \% \mathrm{NaCl}$} \\
\hline Co & 10.2 & 1.00 & $1.01(99.1)$ & $1.11(88.6)$ \\
\hline $\mathrm{Ni}$ & 7.5 & 1.00 & 0.98 (98.5) & $1.02(98.5)$ \\
\hline $\mathrm{Cd}$ & 3.2 & 1.00 & $1.66(33.8)$ & $1.63(36.7)$ \\
\hline $\mathrm{Pb}$ & 21.8 & 1.00 & $0.97(97.2)$ & $0.98(98.2)$ \\
\hline \multicolumn{5}{|c|}{ Mixed metal in ground water } \\
\hline Co & - & 1.00 & - & $0.82(82.2)$ \\
\hline $\mathrm{Ni}$ & - & 1.00 & - & $1.01(99.0)$ \\
\hline $\mathrm{Cd}$ & - & 1.00 & - & $0.96(96.3)$ \\
\hline $\mathrm{Pb}$ & - & 1.00 & - & $0.82(82.2)$ \\
\hline \multicolumn{5}{|c|}{ Mixed metal in $3 \% \mathrm{NaCl}$} \\
\hline $\mathrm{Cd}$ & 3.2 & 1.00 & - & $0.77(77.0)$ \\
\hline Co & 10.2 & 1.00 & - & $0.76(76.5)$ \\
\hline $\mathrm{Eu}$ & 22.7 & 1.00 & - & $0.81(80.7)$ \\
\hline $\mathrm{Fe}$ & 94.7 & 1.00 & - & $1.12(88.0)$ \\
\hline Mn & 28.8 & 1.00 & - & $0.92(91.9)$ \\
\hline $\mathrm{Ni}$ & 7.5 & 1.00 & - & $1.25(74.6)$ \\
\hline $\mathrm{Pb}$ & 21.8 & 1.00 & - & $1.01(99.1)$ \\
\hline $\mathrm{Ti}$ & 42.7 & 1.00 & - & $0.57(57.3)$ \\
\hline
\end{tabular}

To explore the preconcentration properties of functionalized silica gels further, DTGS was used to preconcentrate eight different metals from a simulated seawater sample. Besides $\mathrm{Co}, \mathrm{Ni}, \mathrm{Cd}$ and $\mathrm{Pb}$, preconcentration was successful also in the case of Europium $(\mathrm{Eu})$, Iron $(\mathrm{Fe})$, and Manganese $(\mathrm{Mn})$. Especially, also rare earth elements (Eu) could be analyzed more precisely after preconcentration step with functionalized silica gels. On the other hand, almost half of the titanium was not concentrated, which might be attributed its very high stability constant with DTPA $(\log K=23.05)$ [30].

\section{CONCLUSION}

The amounts of harmful heavy metals are directly affecting to the quality of waters thus making the removal of them highly important. In the present study the metal removal 
properties of two modified silica-based adsorbents were tested. According to the results both EDTA- modified (EDSG) and DTPA- modified (DTSG) silica gels were efficient adsorbents for all the investigated metal cations. According to the adsorption modeling studies the BiLangmuir model was the most illustrative to simulate the metal adsorption phenomena except in the case of $\mathrm{Pb}$. This indicated that the studied adsorbents had at least two different sites with different functional groups for metal binding. The major advantage of the studied adsorbents was that both could be regenerated with nitric acid for subsequent use. Therefore nitric acid was also found as effective eluent for metals in preconcentration studies. Obtained results were rather promising indicating a possibility to analyze metals at trace concentrations in pure, saline, and ground water samples after preconcentration.

\section{NOMENCLATURE}

$\begin{array}{ll}\% R E & \text { regeneration efficiency } \\ b_{\mathrm{T}} & \text { Toth adsorptive potential constant } \\ C_{\mathrm{e}} & \text { equilibrium concentration } \\ C_{\mathrm{i}} & \text { initial concentration } \\ E & \text { Dubinin-Radushkevich adsorption energy } \\ K_{\mathrm{BL} 1 / 2} & \text { BiLangmuir affinity constants } \\ K_{\mathrm{F}} & \text { Freundlich adsorption constant } \\ K_{\mathrm{L}} & \text { Langmuir affinity constant } \\ K_{\mathrm{RP}} & \text { Redlich-Peterson affinity constant } \\ K_{\mathrm{S}} & \text { Sips affinity constant } \\ l_{\mathrm{og}} K & \text { stability constant } \\ M & \text { mass of adsorbent } \\ n_{\mathrm{F}} & \text { Freundlich adsorption constant } \\ n_{\mathrm{RP}} & \text { Redlich-Peterson heterogeneity factor } \\ n_{\mathrm{S}} & \text { Sips heterogeneity factor } \\ n_{\mathrm{T}} & \text { Toth's heterogeneity factor } \\ q_{\mathrm{e}} & \text { equilibrium adsorption capacity } \\ q_{\mathrm{L}} & \text { Langmuir maximum ads. capacity } \\ q_{\mathrm{mBL} 1 / 2} & \text { BiLangmuir maximum ads. capacities } \\ q_{\mathrm{mDR}} & \text { Dubinin-Radushkevich maximum ads. capacity } \\ q_{\mathrm{mT}} & \text { Toth maximum ads. capacity } \\ q_{\mathrm{o}} & \text { adsorption capacity of fresh adsorbent } \\ q_{\mathrm{RP}} & \text { Redlich-Peterson maximum ads. capacity } \\ q_{\mathrm{r}} & \text { adsorption capacity of regenerated adsorbent } \\ q_{\mathrm{S}} & \text { Sips maximum ads. capacity } \\ V & \text { volume of the solution } \\ & \\ & \end{array}$

$[\%]$
$[1 / \mathrm{mmol}$ or $1 / \mathrm{mg}]$
$[\mathrm{mmol} / \mathrm{l}$ or $\mathrm{mg} / \mathrm{l}]$
$[\mathrm{mmol} / \mathrm{l}$ or $\mathrm{mg} / \mathrm{l}]$
$[\mathrm{kJ} / \mathrm{mol}]$
$[1 / \mathrm{mmol}$ or $1 / \mathrm{mg}]$
$[-]$
$[1 / \mathrm{mmol}$ or $1 / \mathrm{mg}]$
$[1 / \mathrm{mmol}$ or $1 / \mathrm{mg}]$
$[1 / \mathrm{mmol}$ or $1 / \mathrm{mg}]$
$[-]$
$[\mathrm{g}]$
$[-]$
$[-]$
$[-]$
$[-]$
$[\mathrm{mmol} / \mathrm{g}$ or $\mathrm{mg} / \mathrm{g}]$
$[\mathrm{mmol} / \mathrm{g}$ or $\mathrm{mg} / \mathrm{g}]$
$[\mathrm{mmol} / \mathrm{g}$ or $\mathrm{mg} / \mathrm{g}]$
$[\mathrm{mmol} / \mathrm{g}$ or $\mathrm{mg} / \mathrm{g}]$
$[\mathrm{mmol} / \mathrm{g}$ or $\mathrm{mg} / \mathrm{g}]$
$[\mathrm{mmol} / \mathrm{g}$ or $\mathrm{mg} / \mathrm{g}]$
$[\mathrm{mmol} / \mathrm{g}$ or $\mathrm{mg} / \mathrm{g}]$
$[\mathrm{mmol} / \mathrm{g}$ or $\mathrm{mg} / \mathrm{g}]$
$[\mathrm{mmol} / \mathrm{g}$ or $\mathrm{mg} / \mathrm{g}]$
$[1]$

\section{REFERENCES}

1. Sung, Y.-H. and Huang, S.-D., On-line Preconcentration System Coupled to Electrothermal Atomic Adsorption Spectrometry for the Simultaneous Determination of Bismuth, Cadmium and Lead in the Urine, Anal. Chim. Acta, Vol. 495, No. 1, pp 165-176, 2003, http://dx.doi.org/10.1016/j.aca.2003.07.009

2. Mondal, M. K., Mishra, G. and Kumar, P., Adsorption of Cadmium (II) and Chromium (VI) from Aqueous Solution by Waste Marigold Flowers, J. Sustain. Dev. Energy Water Environ. Syst., Vol. 3, No. 4, pp 405-415, 2015, http://dx.doi.org/10.13044/j.sdewes.2015.03.0030

3. Fu, F. and Wang, Q., Removal of Heavy Metal Ions from Wastewaters: A Review, J. Environ. Manage., Vol. 92, No. 3, pp 407-418, 2011, http://dx.doi.org/10.1016/j.jenvman.2010.11.011 
4. Sharma, Y. C., Srivastava, V., Singh, V. K., Kaul, S. N. and Weng, C. H., Nano-adsorbents for the Removal of Metallic Pollutants from Water and Wastewater, Environ. Technol., Vol. 30, No. 6, pp 583-609, 2009, http://dx.doi.org/10.1080/09593330902838080

5. Strelko Jr., V., Malik, D. J. and Streat, M., Interpretation of Transition Metal Sorption Behavior by Oxidized Active Carbons and other Adsorbents, Sep. Sci. Technol., Vol. 39, No. 8, pp 1885-1905, 2004, http://dx.doi.org/10.1081/SS-120030791

6. Wang, J. and Chen, C., Biosorbents for Heavy Metals Removal and their Future, Biotech. Adv., Vol. 27, No. 2, pp 195-226, 2009, http://dx.doi.org/10.1016/j.biotechadv.2008.11.002

7. Bankauskaite, A., Eisinas, A., Baltakys, K. and Zadaviciute, S., A Study on the Intercalation of Heavy Metal Ions in a Wastewater by Synthetic Layered Inorganic Adsorbents, Des. Wat. Treat., Vol. 56, No. 6, pp 1576-1586, 2015, http://dx.doi.org/10.1080/19443994.2014.951074

8. Misaelides, P., Application of Natural Zeolites in Environmental Remediation: A Short Review, Microp. Mesop. Mater., Vol. 144, No. 1, pp 15-18, 2011, http://dx.doi.org/10.1016/j.micromeso.2011.03.024

9. Gautam, R. K., Mudhoo, A., Lofrano, G. and Chattopadhyaya, M. C., Biomass-derived Biosorbents for Metal Ions Sequestration: Adsorbent Modification and Activation Methods and Adsorbent Regeneration, J. Environ. Chem. Eng., Vol. 2, No. 1, pp 239-259, 2014, http://dx.doi.org/10.1016/j.jece.2013.12.019

10. Gupta, V. K., Tyagi, I., Agarwal, S., Moradi, O., Sadegh, H., Shahryari-ghoshekandi, R., Makhlouf A. S. H., Goodarzi, M. and Garshasbi, A, Study on the removal of Heavy Metal Ions from Industry Waste by Carbon Nanotubes: Effect of the Surface Modification - A Review, Critic. Rev. Env. Sci. Tech., Vol. 46, No. 2, pp 93-118, 2015, http://dx.doi.org/10.1080/10643389.2015.1061874

11. Repo, E., Warchoł, J. K., Bhatnagar, A., Mudhoo, A. and Sillanpää, M., Aminopolycarboxylic Acid Functionalized Adsorbents for Heavy Metals removal from Water, Water Res., Vol. 47, No. 14, pp 4812-4832, 2013, http://dx.doi.org/10.1016/j.watres.2013.06.020

12. Repo, E., Kurniawan, T. A., Warchol, J. K. and Sillanpää, M. E. T., Removal of Co (II) and $\mathrm{Ni}$ (II) Ions from Contaminated Water using Silica Gel functionalized with EDTA and/or DTPA as Chelating Agents, J. Hazard. Mater., Vol. 171, No. 1, pp 1071-1080, 2009, http://dx.doi.org/10.1016/j.jhazmat.2009.06.111

13. Repo, E., Petrus, R., Sillanpää, M. and Warchoł, J. K., Equilibrium Studies on the Adsorption of Co (II) and Ni (II) by modified Silica Gels: One-component and Binary Systems, Chem. Eng. J., Vol. 172, No. 1, pp 376-385, 2011, http://dx.doi.org/10.1016/j.cej.2011.06.019

14. Zhao, C., Ma, L., You, J., Qu, F. and Priestley, R. D., EDTA-and Amine-functionalized Graphene Oxide as Sorbents for Ni (II) Removal, Des. Wat. Treat., Vol. 57, No. 19, pp 8942-8951, 2016, http://dx.doi.org/10.1080/19443994.2015.1025438

15. Tan, Z., Peng, H., Liu, H., Wang, L., Chen, J. and Lu, X., Facile Preparation of EDTA-functionalized Chitosan Magnetic Adsorbent for removal of Pb (II), J. Appl. Pol. Sci., Vol. 13, No. 32, 2015, http://dx.doi.org/10.1002/app.42384

16. Poehle, S., Schmidt, K. and Koschinsky, A. Determination of Ti, Zr, Nb, V, W and Mo in Seawater by a New Online-preconcentration Method and Subsequent ICP-MS Analysis, Deep Sea Research Part I: Oceanographic Research Papers, Vol. 98, pp 83-93, 2015, http://dx.doi.org/10.1016/j.dsr.2014.11.014

17. Dehouck, P., Cordeiro, F., Snell, J. and de la Calle, B., State of the Art in the Determination of Trace Elements in Seawater: A Worldwide Proficiency Test, Anal. Bioanal. Chem., Vol. 408, No. 12, pp 3223-3232, 2016, http://dx.doi.org/10.1007/s00216-016-9390-6 
18. Søndergaard, J., Asmund, G. and Larsen, M. M., Trace Elements Determination in Seawater by ICP-MS with On-line Pre-concentration on a Chelex-100 Column using a 'Standard' Instrument Setup, Methods X, Vol. 2, pp 323-330, 2015, http://dx.doi.org/10.1016/j.mex.2015.06.003

19. Lee, J. M., Boyle, E. A., Echegoyen-Sanz, Y., Fitzsimmons, J. N., Zhang, R. and Kayser, R. A., Analysis of Trace Metals $(\mathrm{Cu}, \mathrm{Cd}, \mathrm{Pb}$, and $\mathrm{Fe})$ in Seawater using Single Batch Nitrilotriacetate Resin Extraction and Isotope Dilution Inductively Coupled Plasma Mass Spectrometry, Anal. Chim. Acta, Vol. 686, No. 1, pp 93-101, 2011, http://dx.doi.org/10.1016/j.aca.2010.11.052

20. Zhao, F., Repo, E., Meng, Y., Wang, X., Yin, D. and Sillanpää, M., An EDTA- $\beta$-cyclodextrin Material for the Adsorption of Rare Earth Elements and its Application in Preconcentration of Rare Earth Elements in Seawater, J. Coll. Inter. Sci., Vol. 465, pp 215-224, 2016, http://dx.doi.org/10.1016/j.jcis.2015.11.069

21. Shiraishi, Y., Nishimura, G., Hirai, T. and Komasawa, I., Separation of Transition Metals using Inorganic Adsorbents modified with Chelating Ligands, Ind. Eng. Chem. Res., Vol. 41, No. 20, pp 5065-5070, 2002, http://dx.doi.org/10.1021/ie020119b

22. Foo, K. Y. and Hameed, B. H., Insights into the Modeling of Adsorption Isotherms Systems, Chem. Eng. J., Vol. 150, No. 1, pp 2-10, 2010, http://dx.doi.org/10.1016/j.cej.2009.09.013

23. Allen, S. J., McKay, G. and Porter, J. F., Adsorption Isotherm Model for Basic Dye Adsorption by Peat in Single and Binary Component Systems, J. Colloids Interface Sci., Vol. 280, No. 2, pp 322-333, 2004, http://dx.doi.org/10.1016/j.jcis.2004.08.078

24. Pérez-Marín, A. B., Meseguer Zapata, V., Ortuño, J. F., Aguilar, M., Saéz, J. and Lloréns, M., Removal of Cadmium from Aqueous Solutions by Adsorption onto Orange Waste, J. Hazard. Mater., Vol. 139, No. 1, pp 122-131, 2007, http://dx.doi.org/10.1016/j.jhazmat.2006.06.008

25. Jossens, L., Prausnitz, J. M., Fritz, W., Sclünder, E. U. and Myers, A. L., Thermodynamics of Multi-solute Adsorption from Dilute Aqueous Solutions, Chem. Eng. Sci., Vol. 33, No. 8, pp 1097-1106, 1978, http://dx.doi.org/10.1016/0009-2509(78)85015-5

26. Vijayraghavan, K., Padmesh, T. V. N., Palanivelu, K. and Velan, M., Biosorption of Nickel(II) Ions onto Sargassum Wightii: Application of Two-parameter and Three-parameter Isotherm Models, J. Hazard. Mater., Vol. 133, No. 1, pp 304-308, 2006, http://dx.doi.org/10.1016/j.jhazmat.2005.10.016

27. Karthikeyan, K. G., Tshabalala, M. A., Wang, D. and Kalbasi, M., Solution Chemistry Effects on Orthophosphate Adsorption by Cationized Wood Residues, Environ. Sci. Technol., Vol. 38, pp 904-911, 2004, http://dx.doi.org/10.1021/es034819z

28. Repo, E., Malinen, L., Koivula, R., Harjula, R. and Sillanpää, M., Capture of Co(II) from its Aqueous EDTA-chelate by DTPA-modified Silica Gel and Chitosan, $J$. Hazard. Mater., Vol. 187, No. 1, pp 122-132, 2011, http://dx.doi.org/10.1016/j.jhazmat.2010.12.113

29. Repo, E., Warchoł, J. K., Bhatnagar, A. and Sillanpää, M., Heavy Metals Adsorption by Novel EDTA-modified Chitosan-silica Hybrid Materials, J. Colloid Int. Sci., Vol. 358, No. 1, pp 261-267, 2011, http://dx.doi.org/10.1016/j.jcis.2011.02.059

30. Hseu, T. M., Wu, S. T. and Lin, Z. F.,The Stabilities and Thermodynamic Properties of Titanium (IV) Chelates of Some Aminopolycarboxylic Acids, J. Chinese Chem. Soc., Vol. 32, No. 4, pp 417-423, 1985, http://dx.doi.org/10.1002/jccs.198500065 